\title{
Parasitological analysis of synovial fluid from dogs naturally infected with Leishmania sp.
}

Análise parasitológica do líquido sinovial de cães naturalmente infectados por Leishmania sp.

\author{
Mayara Nobrega Gomes da Silva ${ }^{\mathrm{I}}$ Deyverson Thiago Prates Pereira ${ }^{\mathrm{I}}$ \\ Maria Ligia de Arruda Mistieri ${ }^{{ }^{*}}$ Irina Lubeck $^{\mathrm{I}}$ João Paulo da Exaltação Pascon $^{\mathrm{I}}$
}

- NOTE -

\section{ABSTRACT}

The aim of this study was to verify the feasibility of synovial fluid (SF) analysis for the parasitological diagnosis of leishmaniasis in naturally infected dogs. Aseptic arthrocentesis of the tarsal and carpal joints of 40 infected dogs (158 Leishmania sp samples) was conducted after euthanasia. The SF smears were evaluated under optic microscopy and amastigotes were detected in the SF of 35 dogs (87.5\%). Of the 93 positive samples, 53\% were obtained from the tarsal joints, and $47 \%$ were obtained from the carpal joints. Amastigote forms were confirmed in one (17\%), two (26\%), three (31\%) or all four investigated joints (26\%). This research highlights the feasibility and high sensitivity of SF evaluation for the parasitological diagnosis of leishmaniasis in symptomatic dogs.

Key words: leishmaniasis, canine, diagnosis, joint.

\section{RESUMO}

O objetivo deste estudo foi verificar a viabilidade da análise do líquido sinovial (LS) para o diagnóstico parasitológico de leishmaniose em cães naturalmente infectados. Artrocenteses assépticas das articulações do tarso e do carpo de 40 cães infectados (totalizando 158 amostras articulares) foram realizadas após a eutanásia. Os esfregaços LS foram avaliados sob microscopia óptica e formas amastigotas de Leishmania sp. foram detectadas no LS de 35 cães (87,5\%). 93 amostras articulares foram positivas, sendo $53 \%$ obtidas a partir das articulações tarsais e $47 \%$ obtidas de articulações carpais. Formas amastigotas foram confirmadas em uma (17\%), duas (26\%), três (31\%) ou todas as quatro articulações investigadas (26\%). Este trabalho destaca a viabilidade e a alta sensibilidade da avaliação LS para o diagnóstico parasitológico de leishmaniose em cães sintomáticos.

Palavras-chave: leishmaniose, canina, diagnóstico, articulação.
Leishmaniasis is an anthropozoonosis caused by Leishmania. A total of 98 countries on 5 continents reported endemic leishmaniasis transmission; official case counts more than 278.000 new cases per year, which are underestimated in one-third of countries which do not have reported data for the last five years (ALVAR et al., 2012). In veterinary medicine, leishmaniasis caused by $\boldsymbol{L}$. infantum is mostly important in dogs, which are considered the main reservoir of this parasite for humans (SOLANO-GALLEGO et al., 2009). This agent is the most important species in the Old World and is synonymous to $L$. chagasi in Central and South America (SOLANO-GALLEGO et al., 2009).

Serological examinations, such as Enzyme-Linked Immunosorbent Assays (ELISAs) and Indirect Fluorescent Antibody Tests (IFATs) are recommended by the World Organization for Animal Health (OIE, 2008) for the diagnosis of leishmaniasis in dogs. However, serological studies, such as IFATs may lead to false-positive results due to cross reactions with other etiological agents like Trypanososma cruzi, Plasmodium sp. or Mycobacterium sp. Nevertheless, serological tests are more expensive than parasitological diagnosis (GONTIJO \& MELO, 2004). Parasitological analysis, on the other hand, has a specificity of $100 \%$ and is cheaper but shows variable sensitivity (SILVA, 2009). Samples of bone marrow, lymph node, spleen and skin lesions are currently used for the parasitological diagnosis of leishmaniasis in naturally infected dogs, however

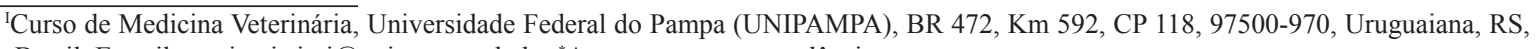
Brasil. E-mail: mariamistieri@unipampa.edu.br. *Autor para correspondência. 
the use of synovial fluid (SF) for this propose has been rarely reported (SARIDOMICHELAKIS et al., 2005; SILVA, 2009). Although arthritis can be diagnosed in dogs with leishmaniasis, it can occur due to immune complex deposition or to the presence of the Leishmania in the joint. Only few case reports have already referred the identification of amastigotes on canine SF (SANTOS et al., 2006; SILVA, 2007). The present study aimed to evaluate the feasibility of SF analysis for the parasitological diagnosis of Leishmania sp. infection in naturally infected dogs.

Forty symptomatic dogs, 20 females and 20 males, were included in this study. The dogs were brought to the Veterinary Hospital of the Federal University of Pampa for euthanasia due to leishmaniasis, according to Brazilian Ministry of Health recommendations. The dogs presented signs like cutaneous lesions, loss of weight, enlarged lynphnodes and dehydration. The infection was confirmed by positivity in both serological tests: ELISA and the IFAT, with the cut-off titer of 1:40 as confirmatory, according to brazilian public health authorities (DANTAS-TORRES et al., 2012). The dogs underwent to general anesthesia with Propofol $\left(\right.$ Propovan $\left.^{\circledR}\right)\left(8 \mathrm{mg} \mathrm{kg}^{-1} \mathrm{IV}\right)$ and euthanasia immediately after the induction, with $\mathrm{KCl} 19.1 \%\left(40 \mathrm{~mL} \mathrm{dog}^{-1}\right.$, IV).

The samples of SF were obtained from both carpal and tarsal joints of each animal, immediately after death, by aseptic arthrocentesis, as described by CLEMENTS (2006), summing up 160 arthrocentesis. The maximum amount of SF was collected using a fine needle $(25 \times 7 \mathrm{~mm})$ and a $3 \mathrm{ml}$ syringe containing $50 \mu \mathrm{L}$ of ethylenediamine tetraacetic acid (EDTA) in order to prevent clot formation.
The smears were prepared on glass slides with $10 \mu \mathrm{L}$, without centrifugation, immediately after arthrocentesis and were stained using the quick panoptic method. Two glass slides were prepared from the SF obtained from each evaluated joint (carpal and tarsal joint). The stained smears were examined under a microscope (1000X) and classified as positive or negative for the presence of Leishmania sp.

Positive parasitological results of carpal and tarsal SF samples were compared using the Standard Frequentist Hypothesis Testing for two proportions (Minitab Statistical Software) (95\% confidence).

The SF-based parasitological examination was positive for Leishmania sp. in 35 of the 40 examined dogs (87.5\%). Amastigote forms were observed in macrophages and neutrophils (Figure 1) or free in the synovia.

From the 160 joints submitted to arthrocentesis, 158 samples of SF (98.75\%) were collected without complications and analyzed. Two tarsal joints from the same dog could not be evaluated due to insufficient material. Of the 158 evaluated samples, 93 were classified as positive, and of these, $49(53 \%)$ were obtained from the tarsal joints and 44 (47\%) from the carpal joints. However no significant differences were observed in the frequency distribution between the two different joint categories. Amastigotes were observed in only one joint for $17 \%$ of the dogs, in two joints for $26 \%$, in three joints for $31 \%$ and in all four evaluated joints for $26 \%$.

Parasitological examination for the diagnosis of leishmaniasis is commonly performed using bone marrow, lymph nodes and spleen aspirates,

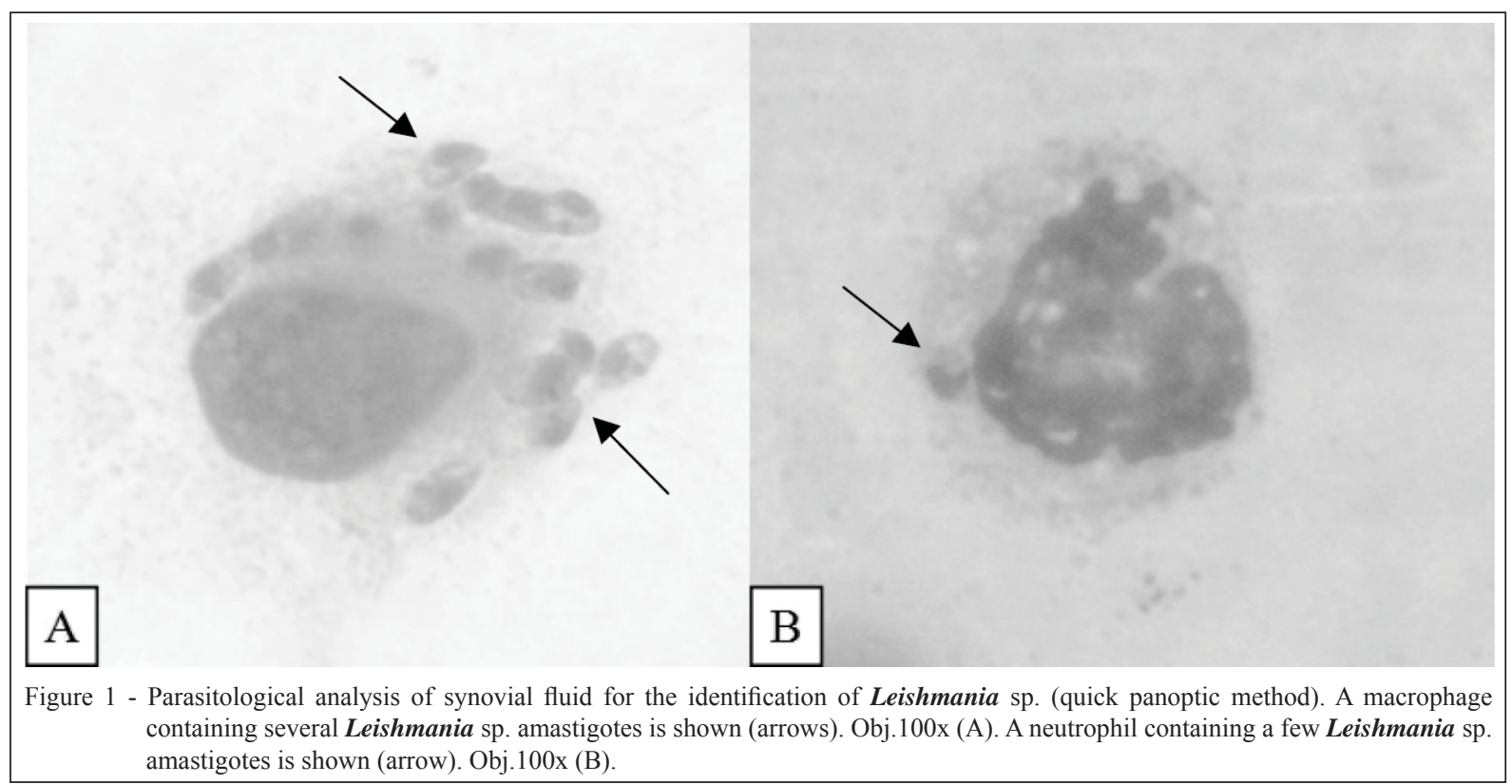

Ciência Rural, v.44, n.7, jul, 2014. 
and the sensitivity of these tests ranges from $30 \%$ to 80\% (SARIDOMICHELAKIS et al., 2005; SOLANOGALLEGO et al., 2009). SF is rarely used for this propose, and the sensitivity of assays using SF has been previously reported to be $23 \%$ in naturally infected dogs and $64 \%$ in experimentally intra-articular inoculated dogs; in both cases, no correlation with clinical symptoms was reported (SILVA, 2007; SILVA, 2009). According to our analyses, the parasitological examination of SF smears had a positivity of $87.5 \%$ for symptomatic naturally infected dogs. Distal joints, such as the carpus and tarsus, are reported to be more easily affected by parasitic arthritis due to hemodynamic factors (SILVA, 2009) and therefore were selected for the SF aspiration. As polyarthritis or joint swelling is still referred as uncommon clinical manifestations of the leishmaniasis infection (SOLANO-GALLEGO et al., 2009), the authors believe it could explain why the parasitological analysis of SF remain underused. However, arthrocentesis and amastigotes identification on SF were simply performed in the present study.

Some complications of arthrocentesis were described on the literature and could interfere on SF analysis. According to CLEMENTS (2006), the most common complication of arthrocentesis is the failure to obtain a synovial fluid sample, but it was observed in only two of the 160 joints in the present study. The contamination of samples with blood during arthrocentesis is considered an occasional complication (CLEMENTS, 2006) but it was not observed in the 160 arthrocentesis. When performed properly, complications of arthrocentesis to dogs are rare, but can include hemarthrosis, localized trauma, pain, and iatrogenic infection. In fact, the technique of arthrocentesis is simple to perform for most peripheral appendicular joints in small animals and is associated with minimal morbidity, but remains underused (BERG et al., 2009).

The sensitivity of parasitological examinations can be affected not only by the origin of the sample but also by the time elapsed between collection, preparation and sample analysis; the time spent on the evaluation; and the number of fields covered (BRUSTOLONI, 2006). This manuscript presents methodological adaptations that probably made the use of SF feasible for the parasitological diagnosis of leishmaniasis, in contrast to the results of other studies (SILVA, 2007; SILVA, 2009). First, EDTA was added to the samples based on the possible presence of joint inflammation and increased levels of fibrinogen, which leads to rapid clot formation in the SF interfering with amastigote visualization (HARRY, 2010). Moreover, the period for slide preparation and analysis was restricted to 24 hours after aspiration, and four joints from each dog were evaluated. This report encourages the use of SF for parasitological leishmaniasis diagnosis in a greater amount of dogs. It should be further tested and compared its sensitivity and complications in dogs with the traditionally aspirates of bone marrow and lymph nodes and for asymptomatic patients.

The parasitological examination of SF for Leishmania sp. was feasible and presented positivity of $87.5 \%$ for symptomatic naturally infected dogs.

\section{ETHICS COMMITTEE}

The present study was approved by the Ethics Committee for the Use of Animals (CEUA) of the Federal University of Pampa (protocol no. 029/2012).

\section{ACKNOWLEDGEMENTS}

Scientific initiation scholarship from the academic development program (PBDA) of the Federal University of Pampa

\section{REFERENCES}

ALVAR, J. et al. Leishmaniasis worldwide and global estimates of its incidence. PLoS ONE, v.7, p.e35671, 2012. Available from: $<$ http:// www.plosone.org/article/info\%3Adoi\%2F10.1371\%2Fjournal. pone.0035671>. Accessed: Set. 01, 2013. doi: 10.1371/jornal. pone. 0035671 .

BERG, R.I.M. et al. Effect of repeated arthrocentesis on cytologic analysis of synovial fluid in dogs. brief communication. Journal of Veterinary Internal Medicine, v.23, p.814-817, 2009. Available from: <http://www.ncbi.nlm.nih.gov/pubmed/19566847>. Accessed: Jul. 07, 2013. doi: 10.1111/j.1939-1676.2009.0340.x.

BRUSTOLONI, Y.M. Leishmaniose visceral em crianças do estado de Mato Grosso do Sul, Brasil: contribuição ao diagnóstico e ao tratamento. 2006. 137f. Tese (Doutorado em Ciências da Saúde) - Curso de Pós-graduação em Ciências da Saúde, Rede Centro-Oeste UnB/UFG/UFMS, Campo Grande, MS.

CLEMENTS, D. Arthrocentesis and synovial fluid analysis in dogs and cats. In Practice, v.28, p.256-262, 2006. Available from: $<$ http://inpractice.bmj.com/content/28/5/256.abstract $>$. Accessed: Jul. 01, 2013. doi: 10.1136/inpract.28.5.256.

DANTAS-TORRES, F. et al. Canine leishmaniosis in the old and new worlds: unveiled similarities and differences. Trends in Parasitology, v.28, p.531-538, 2012. Available from: $<$ http://www.cell. $\mathrm{com} /$ trends/parasitology//retrieve/pii/S147149221200147X?cc=y $>$. Accessed: Jul. 03, 2013. doi: 10.1016/j.pt.2012.08.007.

GONTIJO C.M.F.; MELO M.N. Leishmaniose visceral no Brasil: quadro atual, desafios e perspectiva. Revista Brasileira de Epidemiologia, v.7, p.338-349, 2004. Available from: <http://www.scielo.br/scielo.php?pid=S1415790X2004000300011\&script $=$ sci_arttext $>$. Accessed: Jul. 07, 2013. doi: 10.1590/S1415-790X2004000300011. 
HARRY, M. Practical assessment of synovial fluid. Companion Animal, v.14, p.52-57, 2010. Available from: $<$ http://onlinelibrary. wiley.com/doi/10.1111/j.2044-3862.2009.tb00369.x/abstract $>$. Accessed: Jul. 07, 2013. doi: 10.1111/j.2044-3862.2009.tb00369.x.

OIE. Manual of diagnostic tests and vaccines for terrestrial animals 6.ed. Paris: Office International des Epizooties, 2008. V.1. 598p.

SANTOS, M. et al. Polyarthritis associated with visceral leishmaniasis in a juvenile dog. Veterinary Parasitology, v.141, p.340-344, 2006. Available from: <http://www.sciencedirect. com/science/article/pii/S0304401706003451>. Accessed: Set. 01, 2013. doi:10.1016/j.vetpar.2006.05.028.

SARIDOMICHELAKIS, M.N. et al. Evaluation of lymph node and bone marrow cytology in the diagnosis of canine leishmaniasis (Leishmania infantum) in symptomatic and asymptomatic dogs. American Journal of Tropical Medicine and Hygiene, v.73, p.82-86, 2005. Available from: <http://www.ncbi.nlm.nih.gov/ pubmed/16014839>. Accessed: Jul. 07, 2013.
SILVA, A.A.L. Estudo clínico-laboratorial das articulações de cães naturalmente infectados com leishmaniose visceral e experimentalmente inoculados com Leishmania chagasi por via intra-articular. 2007. 66f. Dissertação (Mestrado em Ciência Animal) - Curso de Medicina Veterinária, Universidade Estadual Paulista "Julio de mesquita Filho", Araçatuba, SP.

SILVA, A.R.S. Avaliação radiográfica das articulações dos membros locomotores de cães naturalmente acometidos por leishmaniose visceral no município de Araçatuba/SP. 2009. 83f. Dissertação (Mestrado em Ciência Animal) - Curso de Medicina Veterinária, Universidade Estadual Paulista "Julio de mesquita Filho", Araçatuba, SP.

SOLANO-GALLEGO, L. et al. Directions for the diagnosis, clinical staging, treatment and prevention of canine leishmaniosis. Veterinary Parasitology, v.165, p.1-18, 2009. Available from: $<$ http://www.ncbi.nlm.nih.gov/pubmed/19559536>. Accessed: Jul. 05, 2013. doi: 10.1016/j.vetpar.2009.05.022. 